\section{Intersections}

Canadian Journal of Music

Revue canadienne de musique
Intersections CANADIAN JOURAL OF MUSIC

\title{
Yrjö Kilpinen: Finnish Composer and German Lieder in the 1930s
}

\section{James Deaville}

Volume 25, numéro 1-2, 2005

Northern Perspectives on Music and Culture

URI : https://id.erudit.org/iderudit/1013310ar

DOI : https://doi.org/10.7202/1013310ar

Aller au sommaire du numéro

\section{Éditeur(s)}

Canadian University Music Society / Société de musique des universités canadiennes

ISSN

1911-0146 (imprimé)

1918-512X (numérique)

Découvrir la revue

Citer cet article

Deaville, J. (2005). Yrjö Kilpinen: Finnish Composer and German Lieder in the 1930s. Intersections, 25(1-2), 171-186. https://doi.org/10.7202/1013310ar
Résumé de l'article

Les lieder du compositeur finnois Yrjö Kilpinen (1892-1959) offrent une intéressante occasion d'étudier l'interaction entre l'identité nationale et les esthétiques musicales présentes dans l'Allemagne nationale-socialiste. Ses chants en allemand, surtout ceux composés sur les textes de Christian Morgenstern, ont connu une grande popularité dans l'Allemagne des années 1930. Ses affinités politiques ont transformé Kilpinen en modèle des idéologues nazis, ce malgré le fait qu'il n'était pas Allemand et composait dans le genre allemand par quintessence qu'est le lied. Les critiques de ses lieder parues dans la presse allemande expliquaient dans le détail les qualités " nordiques " de l'œuvre de ce compositeur " aryen ». Une étude plus approfondie des Lieder um den Tod révèle une technique compositionnelle rigide, parfois même maladroite, qui s’adaptait bien à l’idéologie politique du Troisième Reich.
Copyright @ Canadian University Music Society / Société de musique des universités canadiennes, 2005
Ce document est protégé par la loi sur le droit d'auteur. L’utilisation des services d’Érudit (y compris la reproduction) est assujettie à sa politique d'utilisation que vous pouvez consulter en ligne.

https://apropos.erudit.org/fr/usagers/politique-dutilisation/ 


\section{YrJö Kilpinen: FinNish Composer ANd German LiEDER IN THE 1930 S $^{1}$}

\section{James Deaville}

Three brief citations to begin this investigation: "As composer of Lieder, [he] has by all means the most productive disposition of this era" (Hapke 1936, 1152). ${ }^{2}$ "Here we have a truly creative talent by the grace of God, whose calling is to say important things within few words" (Graener 1937, 5). ${ }^{3}$ "[He is] the greatest lyricist of the age and a master of song of the highest calibre" (anonymous German critic from 1934, cited and translated in Korhonen 2003, 71). We might expect that such encomia from the German press of the 1930s were directed at a native-born Lied composer, who (in light of such favourable comments at that time) must have been a member of the National Socialist party. But the recipient was a Finnish musician, who nevertheless came to be regarded as one of the leading composers of German Lieder during the 1930s. Yrjö Kilpinen certainly exhibited talent and fecundity as a composer of Lieder, but there was another factor that contributed to his popularity in the Germany of the mid-1930s: he was a National Socialist sympathizer. ${ }^{4}$ This historical fact caused some Finnish music historians discomfort to the extent that Kilpinen tended to be passed over in silence during the post-war years. When he was mentioned in that literature, Kilpinen's ideology of the 1930s and early 1940s rarely figured in later assessments of the man and his music. ${ }^{5}$

1 For their valuable comments on and contributions to this study, I wish to extend my heartfelt thanks to Tomi Mäkelä (University of Magdeburg), Helena Tyrväinen (University of Helsinki), Michael Saffle (Virginia Tech) and the anonymous Finnish reviewer of this article. That reviewer also made me aware of how Finland's relationship with Nazi Germany remains a difficult and sensitive issue in the country. Kilpinen's daughter Siipi Saari has unfortunately not made his material accessible to scholars (even though it has been catalogued in the Finnish National Archives since 1999), which renders Kilpinen a difficult topic for research. However, since this paper treats his reception in German-speaking Europe, the question of access to primary sources in Finland is less of a problem. All translations from German texts are by the author.

2 "Yrjö Kilpinen ... ist als Liederkomponist überhaupt die produktivste Natur unserer Epoche."

3 "Hier handelt es sich um ein ernsthaft schöpferisches Talent von Gottes Gnaden, dem es gegeben ist, große Dinge in kleinem Rahmen zu sagen."

4 The inaccessibility of his correspondence makes it difficult to determine his personal level of allegiance to fascism and the National Socialists, for he may well have been an opportunist. A clear identification of Kilpinen's political sympathies will have to await the opening of the archival holdings.

5 This reluctance to deal with his political past is even evident in such standard Kilpinen literature as the monographs about him by Tauno Karila and Tarja Taurula. More recently, however, Finnish scholars like Tomi Mäkelä and Erkki Salmenhaara have attempted to come to grips with the problem of Kilpinen. See above all Salmenhaara's Uuden musiikin kynnyksellä. Suomen musiikin historia, 494-503, for a detailed account of Kilpinen's connections with Germany. 
This study explores the historical oddity of a non-German composer achieving success in the quintessentially German genre of the Lied during the Third Reich, and tries to make sense of it. As we shall see, the appropriation of German poetry and musical aesthetics in Kilpinen's Lieder made him a showcase for Nordic/Aryan cultural supremacy. As an internationally recognised composer who seemingly embraced the politics of Hitler, he was, for propaganda purposes, even more valuable to the Nazis. ${ }^{6}$ However, his association with National Socialism has rendered Kilpinen a difficult commodity for subsequent generations of Finnish music historians. ${ }^{7}$

\section{OpPortunist or Collaborator?}

Born on 4 February 1892 in Helsinki, Kilpinen studied with Erik Furuhjelm at the local conservatory intermittently between 1908 and 1917, while taking lessons from Richard Heuberger in Vienna (1910-11) and from Paul Juon in Berlin (1913-14). He acquired a good knowledge of German during these and other visits or residencies. As is evidenced by his song settings, Kilpinen developed an interest in poetry by Rilke and Morgenstern and songs by Schubert and Wolf, among others. If the early 1920 s were characterized by his composition of songs to Nordic texts, from the late 1920s through the end of the war, Kilpinen dedicated himself almost exclusively to setting Germanlanguage poetry, which has led commentators to identify those years as a second or German period in his creative production. ${ }^{8}$

Whilst this was for Kilpinen a time of growing expertise as a composer and of rising notoriety in his homeland, the 1920 s were also a period of increasing political activity in Finland on the part of nationalist and eventually right-wing groups. The Academic Karelia Society (Akateeminen Karjala-Seura, AKS) was "a group of academics, intellectuals and literati who advocated anti-communism ... authoritarian government, the elimination of non-Finnish influences from Finnish life and culture, the creation ... of a Greater Finland extending eastward as far as the Urals" (Blinkhorn 2000,51) and the aggressive promotion of Lutheranism (Larsen 1990, 241). Flourishing at the end of the 1920s, Lapuan liike (Lapua Movement) was a political movement that adopted more extreme measures to promote an anti-communist agenda. ${ }^{9}$ Banished in 1932 after a failed coup

6 In her monograph Der unpolitische Komponist als Politikum: Die Rezeption von Jean Sibelius im NS-Staat, 77-148, Ruth-Maria Gleißner makes a strong case for the political and ideological utility Finland and Finnish culture had for National Socialist Germany.

7 It stands to reason that a work published shortly after the war like Veikko Helasvuo's Sibelius and the Music of Finland would not refer to issues of complicity with the National Socialists, but publications of the Finnish Music Information Centre continue this practice (Korhonen, 2003). One should remember at the same time that the purpose of the Centre is to promote Finnish music, so its publications may be expected to put that repertory and its composers in a favourable light.

8 See, for example, Salmenhaara 1992, 2.

9 An informative document about Lapuan liike is the brief brochure from 1930 by Lauri Ingman, entitled Die Lapua-Bewegung in Finnland. This publication was clearly intended for consumption in Germany, which is interesting insofar as its strongly anti-communist politics predate the coming-topower of the National Socialists in Germany. 
attempt, Lapuan liike was directly replaced by the national socialist party, Isänmaallinen kansanliike (Patriotic People's Movement, IKL), which pursued its activities until 1944, following the forced Armistice with the Soviet Union. Kilpinen's level of association with these groups remains undocumented, but even the supposedly apolitical Sibelius was an early enthusiast for Lapuan liike (Gleißner 2002, 32-33). ${ }^{10}$

By 1923, Kilpinen had established himself as one of Finland's leading composers, albeit in one genre: song. In all, he would compose over 750 songs in Finnish, Swedish and German in a series of cycles and collections, thereby giving rise to the epithet of "the Finnish Schubert." The earliest songs are in Finnish, but as he became politically active, German poetry came to dominate his text settings of the late 1920s and the 1930s. He favoured composing music to the poems of Christian Morgenstern, which yielded over 75 Lieder. The German and Finnish songs attracted attention in Germany above all through the activities of the well-known singer Gerhard Hüsch, who frequently performed in Cologne and Berlin. One of the high points of the 1930s for Kilpinen was the highly acclaimed performance of his Morgenstern cycle Lieder um den Tod at the 1935 Tonkünstlerfest in Hamburg, which called forth "endless applause," according to a review in the Zeitschrift für Musik (Pfohl 1935, 753). His music remained in the repertory of German concert life even in the early 1940s, albeit not as strongly represented as that of his Finnish compatriot Sibelius. ${ }^{11}$

As Tomi Mäkelä notes in his Kilpinen entry for the revised MGG, the composer not only promoted his music in Nazi Germany but also "actively contributed to the cultural relations between the Third Reich and Finland" (Mäkelä 2003, 100). ${ }^{12}$ This included his involvement in the "Ständiger Rat für internationale Zusammenarbeit der Komponisten," the organisation established in 1934 to foster ties with like-minded composers outside of Germany, and his participation as one of only two foreign jurors (the other was Francesco Malipiero) on the committee of over ten party stalwarts who adjudicated the Olympic composition competition in 1936. His music was featured at two important international festivals of the Third Reich: the aforementioned 1935 Tonkünstlerfest of the Allgemeiner Deutscher Musikverein which, with the collaboration of the Ständiger Rat, became a celebration of music from allied and associated countries, ${ }^{13}$ and the Internationales Zeitgenössisches Musikfest in Baden-Baden that extended from 1936 to $1939 .{ }^{14}$ One further sign of his collaboration, but on

10 According to Gleißner, Sibelius never joined the Isänmaallinen kansanliike.

11 Although Kilpinen is represented with only one work in Wilhelm Altmann's "Statistischer Uberblick über die im Winter 1941/42 stattfindenden Reihenkonzerten" (Altmann 1942, 54-61 and 102-10) compared with 23 works by Sibelius, we should remember that Kilpinen wrote no music for orchestral performance. In terms of German recordings, Kilpinen actually surpassed Sibelius in the Electrola catalogue for 1938/39, with 24 individual recordings to only 16 for Sibelius (Gleißner 2002, 245).

12 "Kilpinen trug aktiv zu den kulturellen Beziehungen zwischen dem NS-Reich und Finnland bei."

13 On the program were works by such composers as Zoltan Kodaly, Franz Schmidt, Franco Alfano, and Jean Sibelius.

14 See Joan Evans, "'International with National Emphasis': The Internationales Zeitgenössisches Musikfest in Baden-Baden, 1936-39." Needless to say, the ideologues of the Third Reich had great use 
Finnish soil, was Kilpinen's role as head of music for the 1940 Olympics in Helsinki, which however had to be cancelled because of the war (Stege 1939, 922).

Kilpinen also nurtured the Finnish-German relationship by publicly promoting Sibelius in the Third Reich by, for example, supporting his compatriot's role as Vice President of the Ständiger Rat (Mäkelä 2003, 100), and by leading the move to establish a Sibelius Society in Germany. ${ }^{15}$ Despite this official upholding of Sibelius as a fellow Nordic master composer, there are other indications that the relationship was strained on a personal level. On one occasion, for example, Kilpinen is said to have almost come to blows with famous Finnish mathematician and amateur musician Rolf Nevanlinna over the merits of Sibelius, which Kilpinen had vehemently disputed. ${ }^{16}$ One source of this hostility was the fact that Kilpinen occupied second place to Sibelius among Finnish composers, even in the hierarchies from Nazi music literature of the Third Reich. ${ }^{17}$

Kilpinen's own political statements are hard to come by, first of all because of the unavailability of his letters in published editions and secondly as a result of the absence of other documents by and about him. ${ }^{18}$ Nevertheless, in an interview with the German newspaper Völkischer Beobachter from 1938, he is quoted as speaking favourably about the German intervention in the Sudeten crisis and about the close collaboration between the Finnish-German Association and the Foreign Ministry of the National Socialist German Workers' Party (Rudolf 1938, 7). His sympathies towards fascism are also evident in the words of party member Paul Graener, who writes about a personal encounter with Kilpinen: "That which was most gratifying was his enthusiasm for the awakening of our people and for our Führer. This person, who in every word, in every glance revealed the integrity of his being, experienced our revolutionary movement as if he were one of us, indeed, felt it more strongly than many of us..." (Graener 1937, 5). Furthermore, there exist a typescript copy of Kilpinen's effusive "Dankesrede beim Dresdner Musikfest des Ständigen Rates $1937^{\prime 19}$ and a published celebratory message by the committed Nazi music historian Herbert Gerigk in honour of the Finnish composer's fiftieth birthday in 1942 (Gerigk 1942, 182). The evidence certainly points to Kilpinen as being more than an opportunistic sympathiser, even though the incontrovertible hard evidence about the true nature of his personal conviction as national socialist is not yet available.

for such non-German "Aryan" composers as Kilpinen, who allowed their names to be associated with international National Socialist events; see also Fred K. Prieberg $(1982,274)$.

15 With Finnish embassy functionary Hans R. Martola, Kilpinen undertook these discussions with the Nordische Gesellschaft during the winter of 1941-42. See the Bundesarchiv (Berlin), NS 15 and NS 18 (Amt Rosenberg und Reichspropagandaleiter der NSDAP) for documentation.

16 Incident recorded by Olli Lehto in Korkeat Maailmat. Rolf Nevanlinnan elämä (Helsinki: Otava, 2001) and cited by Manfred Stern in a review: "Olli Lehto: Erhabene Welten. Das Leben Rolf Nevanlinnas," in: Electronic Mathematics Library (2003), p. 11. http://www.emis.de/misc/articles/lehto. html (accessed May 6, 2005).

17 See, for example, the comments of Fritz Stege in his "Sibelius und die nordische Tonwelt. Zum 70. Geburtstag des finnischen Meisters" $(1936,44-50)$, or the survey of Walter Hapke in "Musik im Rundfunk. Reichssender Hamburg" $(1936,1152)$.

18 Again, the family's reluctance to make these materials accessible is a major reason for these difficulties.

19 Bundesarchiv (Berlin), 2300, 0151/07 (previously Berlin Document Center). 


\section{Kilpinen's Lieder UM DEN ToD [SONgS OF Death] Op. 62}

Still, Kilpinen was not a German, and yet he was setting poetic words to music in that most quintessentially German genre of Lied. Indeed, for Nazi ideologues, the Lied was a bearer of German identity: "For us Germans, the Lied has always been a sung confession of the soul and a mirror of the life of the people" (Schulz, 1934). ${ }^{20}$ In light of this, how could the National Socialist music aestheticians justify the German Lieder of the Finn? A careful reading of the German musical press on Kilpinen, above all a feature article about him in the Zeitschrift für Musik of September, 1939, yields insight into how this non-German could master the Lied. ${ }^{21}$ In that article, Kilpinen enthusiast Fritz Stege argues primarily for the composer's Nordic spirit, which-as Stege foregrounds through an introductory epigram by the notorious racial "scientist" Hans F. K. Günther-implies a "Weltanschauung for which the elevation [Steigerung] of the human is a command of God" (Stege 1939, 922).22 Stege sees the Nordic element revealed not in the superficiality of tone painting but rather to the extent that the landscape is assimilated within the artist. Above all, Stege positions the Nordic artist vis-à-vis the endlessness of the landscape: "This 'Nordic yearning' is a natural sensation for all of those who because of spiritual oppression strive [to go out] into the endless landscape" (Stege 1939, 922). ${ }^{23}$

Once Stege has established the spiritual essence and unity of the Nordic countries in one Aryan Volk, he can proceed to establish the special nature of the integral musical relationships between Germany and Finland, ${ }^{24}$ which manifested itself in the German activities of composers like Sibelius, Selim Palmgren, Toivo Kuula and Kilpinen. The Finnish composer is "the prophet of his surroundings, which encompass him daily, even hourly, in unadulterated, pure form. He himself is the voice of his country, the echo of the soul of the people. In him, centuries of history come alive, become word and tone" (Stege, 1939, 922). ${ }^{25}$ Given his "Nordic soul," his rootedness in the history, landscape and folk music of his country, Kilpinen possessed all of the qualities

20 " $\mathrm{Zu}$ allen Zeiten ist uns Deutschen das Lied ein gesungenes Bekenntnis der Seele und ein Spiegel des Volkslebens gewesen" (Schulz, 1934; cited in Frommann 1999, 20).

21 Among the many German sources of the period about the Lied, Ernst Bücken's Das deutsche Lied: Probleme und Gestaltern provides possibly the most comprehensive overview of the genre, including as well a survey of Lied production of the time.

22 "Der nordische Gedanke ist Ausdruck einer Weltanschauung, welcher die Steigerung des Menschen ein göttliches Gebot ist." Stege also promoted the music of Sibelius, as is most evident in his "Sibelius und die nordische Tonwelt ..."

23 "Die 'nordische Sehnsucht' ist ein natürliches Empfinden all derer, die aus seelischer Bedrängnis heraus in die Weite streben ..."

24 For a more detailed discussion of Third Reich musical ideologies and aesthetics, see Gleißner (2002, 87-131).

25 "Er wird zum unmittelbaren Künder seiner Umwelt, die ihn in unverfälschter, reiner Form täglich, stündlich umgibt. Er selbst ist die Stimme seines Landes, das Echo der Volksseele, in ihm werden Jahrhunderte der Geschichte lebendig, wandeln sich zu Wort und Ton." 
to satisfy Nazi aestheticians, despite the hazy and inconsistent details of their aesthetic ideology. 26

In the most circumspect analysis of Kilpinen's work from Nazi Germany, Stege regards the composer's 1926 Finnish songs, Tunturilauluja (Songs of the Fells, Opp. 52-54) as drawing upon generally Nordic and specifically Finnish musical characteristics, which include the melodic use of consecutive fourths and whole tones, pentatonicism, narrow melodic range, the preference for falling lines, and a general economy of musical materials (Stege 1939, 925-29). The analyst hereby suggests an "ethnic" basis for the music, referring to the harmonic instability as indicative of the Nordic "sense of endlessness" (Unendlichkeitsgefühl). Of course, the analyst makes a strong case for the composer's sensitivity to the nuances of the Finnish language.

This may be fine and well for songs in Kilpinen's native tongue, but what about his settings of German poetry? For Stege and other commentators this was no special problem, since the Nordic peoples (including Germans) are one Volk (even though the Finns are not Indo-Europeans). Kilpinen's choice to set German poetry reflects his inner allegiance with "das Vaterland," especially through his preference for the valued Christian Morgenstern, whose work enjoyed a certain popularity during the Third Reich. ${ }^{27}$ Turning from the Finnish settings of his earlier career stage to the German poetry of his maturity, Kilpinen "succeeded with [this] artistic metamorphosis by exchanging the endlessness of the landscape with [its] spiritual breadth. As the nature of [Kilpinen's] homeland knows no boundaries and extends into the cosmos, Morgenstern broadens the limits of the soul and opens the mystic's gaze for the wonders of the eternal" (Stege 1939, 924). ${ }^{28}$ This broad, quasi-spiritual justification for Kilpinen's setting of German Lieder seemed to obviate the need for close, detailed analysis of these works, which none of the German, Nazi-era commentators on Kilpinen provide. Graener assesses the Finn's German Lieder with the following, typical words: "The gifted Nordic musician Kilpinen always finds the right and true tones for these German words. As a result, and because of their great, austere beauty, these Lieder belong to us, and we should make room for them in our hearts" (Graener 1937, 5-6). ${ }^{29}$ Still, is there any specific justification in the music for

26 This is especially apparent upon close examination of any composer's changing fate during the Third Reich, represented for example by Joan Evans's exhaustive study "Stravinsky's Music in Hitler's Germany" (2003, 525-94).

27 In his extended Kilpinen study of 1939, Stege wrote at length about Morgenstern's importance for Kilpinen, as a bridge between German and Nordic sensibilities (924). One sign of the poet's continuing place within the literary pantheon of Nazi Germany was the 1944 reprint of Morgenstern's Galgenlieder by Insel Verlag in Leipzig.

28 "Dem Tondichter Kilpinen gelingt die künstlerische Metamorphose in der Vertauschung der landschaftlichen Unendlichkeit mit der seelischen Weite. Wie die Natur seiner Heimat keine Grenzen kennt und in das All hineinwächst, so erweitert Morgenstern die Schranken der Seele und öffnet den Blick des Mystikers für die Wunder des Jenseits ..."

29 “... Der geistvolle nordische Musiker Kilpinen findet immer die richtigen und echten Töne für diese deutschen Worte. Darum und wegen ihrer großen herben Schönheit gehören diese Lieder zu 
the epithets Kilpinen earned in Germany, that of the Finnish Schubert or Wolf? To answer that, we will have to take a closer look at the German songs. Since the Morgenstern cycle Lieder um den Tod ("Songs of Death") had the largest circulation and greatest renown in the Germany of the 1930s, we will examine those Lieder, which one recent commentator has designated as "the greatest of [Kilpinen's] printed Morgenstern songs" (Buckbee 1988, 26).

The six songs, as presented in the Table 1 below, form a cycle, through Kilpinen's constructed poetic narrative. He assembled the poems himself from several of Morgenstern's collections, so the texts themselves did not originally have cyclical connections. A reading of the selected poetry reveals how the composer was true to his chosen title: each deals with some aspect of death. A closer analysis uncovers a certain progression, from the bleak pessimism of "Vöglein Schwermut" (\#1)-by far the most frequently set of the six poems (Hans G. Wilhelm Petersen, Heinz Tiessen, Felix Weingartner, Alexander von Zemlinsky, among others) - to the hope in death of "Unverlierbare Gewähr" (\#6). Between those antipodes, the poems set different moods: "Der Tod und der einsame Trinker" (\#3), for example, introduces an element of humour (or rather irony), while "Winternacht" (\#4) is sentimental in its address to the beloved departed. Stege argues that these (and other) Morgenstern poems reflect his "depth of feeling" and "spiritual breadth," which Kilpinen musically translates into the "endlessness of landscape" (Stege 1939, 924).

Table 1.

Yrjö Kilpinen, Lieder um den Tod, Op. 62, Christian Morgenstern, poetry

\begin{tabular}{||l|l|}
\hline Kilpinen: Lieder um den Tod & Morgenstern sources \\
\hline No. 1 "Vöglein Schwermut" & Auf vielen Wegen (1897) \\
No. 2 "Auf einem verfallenen Kirchhof" & Auf vielen Wegen (1897) \\
No. 3 "Der Tod und der einsame & Auf vielen Wegen (1897) \\
Trinker: Eine Mitternachtszene" & \\
No. 4 "Winternacht" & Ich und die Welt (1898) \\
No. 5 "Der Säemann" & individual publication \\
No. 6 "Unverlierbare Gewähr" & individual publication \\
\hline
\end{tabular}

However, the music does not reinforce the creation of a new cyclical unity. The composer's strong crafting of individual identities for each song weakens any sense of shared themes or musical progress, except for the last song "Unverlierbare Gewähr," which in its gentle tone and tender last measures brings the set to a hopeful close. However, contrary to an assessment in the Finnish Music Quarterly by G.L. Buckbee, who finds that song's unbroken 
opening series of 19 2-3 suspensions in the piano "comforting in their hymn-like serenity" (Buckbee 1988, 29), one could hear them as overdone, like a caricature, or on the other hand, like a statement of how an iron will and firm hand can make these notes fulfil their destiny (Example 1). Is this the sought-after articulation of the Nordic Unendlichkeitsgefühl in music?

A similarly elemental recurring accompaniment pattern unifies the first

\section{Unverlierbare Gewähr}

(Chriatinn Mforganatern)

\section{Sure and Certain Hope}

English translation by Olive Burnaby

Yrjö Kilpinen, Op.62 Nr.6
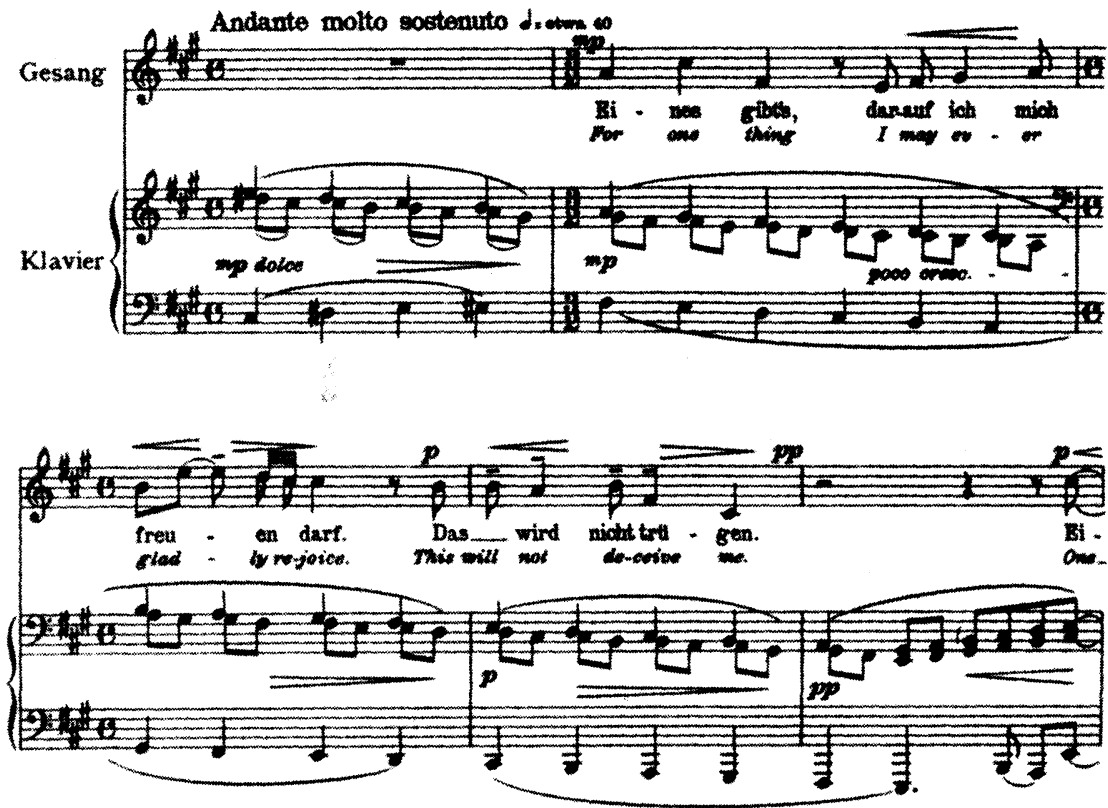

Example 1. Yrjö Kilpinen, /Lieder um den Tod/, Op. 62, No. 6: "Unverlierbare Gewähr," bars 1-5. @ Boosey \& Hawkes/Bote \& Bock, Berlin. Reprint with kind permission.

song for 44 of its 57 bars (Example 2). In and of itself, the pattern's tonal ambiguity creates interest and tension: the missing third and the raised fourth degree weaken the sense of $G$ Minor, which the voice establishes all too clearly upon its entry. However, the 32 unchanging statements of that four-note right-hand pattern, without significant contrast, may well strike the listener as unnecessarily obvious (and tedious) while putting to music "the mystic's gaze for the wonders of the eternal" (Stege 1939, 924). 


\section{LIEDER UM DEN TOD} SONGS OF DEATH

(1)

\section{Vöglein Schwermut

Eugliub tranelation by Olivo Burnaby

\section{The Little Bird Despair}
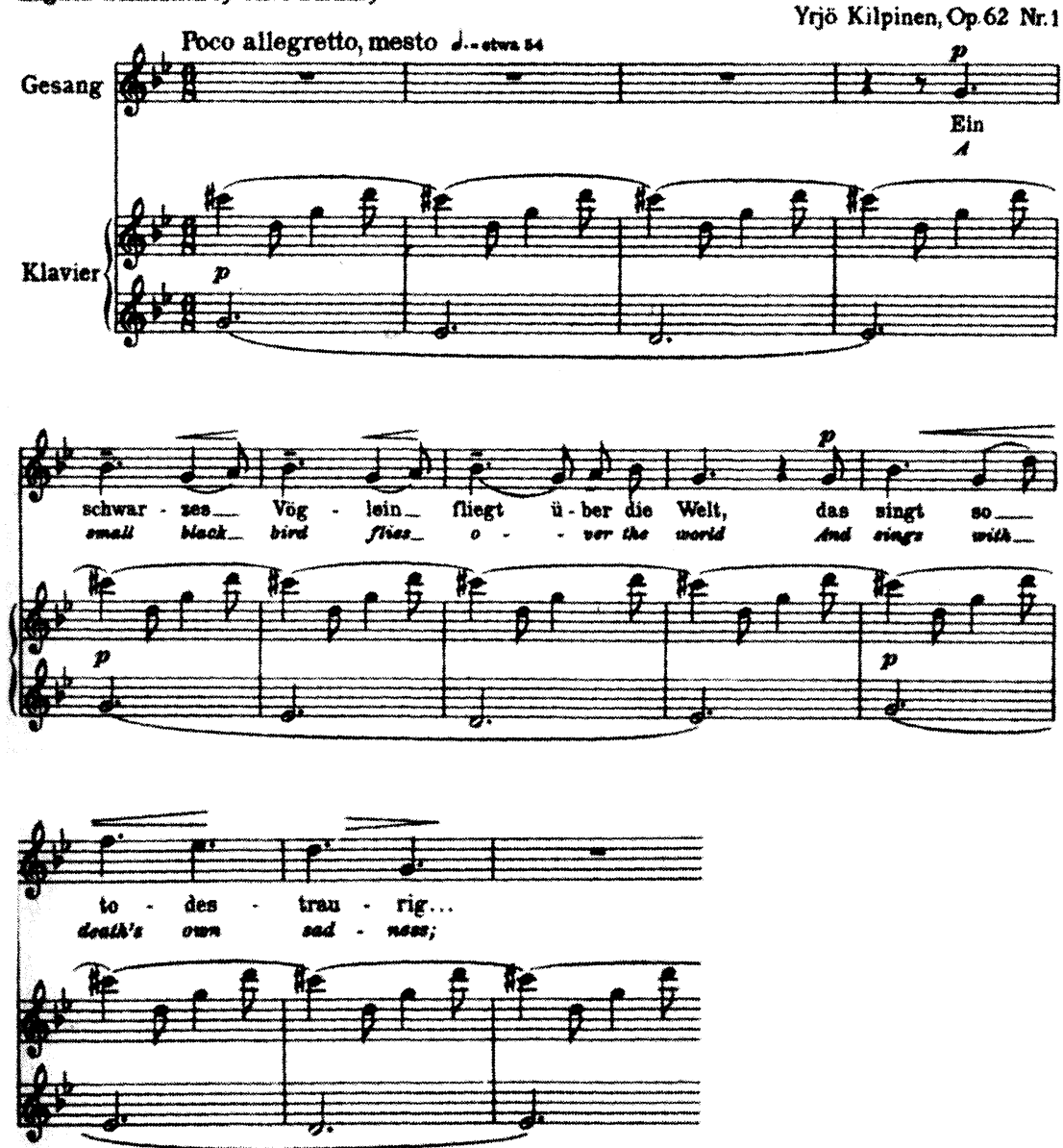

Example 2. Yrjö Kilpinen, /Lieder um den Tod/, Op. 62, No. 1: "Vöglein Schwermut," bars 1-12. () Boosey \& Hawkes/Bote \& Bock, Berlin. Reprint with kind permission. 
The most celebrated of Kilpinen's Lieder um den Tod is No. 3, "Der Tod und der einsame Trinker: Eine Mitternachtsszene." Buckbee goes so far as to call it "one of the world's great Lied compositions-so true, so right, so simple" (Buckbee 1988, 26) (Example 3). In a more interesting musical setting than the prior two examples, we encounter here the contradiction within Kilpinen's work. Is this an effective dramatic song that makes its point through simple repetition of elemental musical ideas and gestures (regardless of how the Nazi ideologues may have appropriated them as representative of the Aryan spirit), or does it become (or is it even intended to be) a parody through the infernal repetition and the increasing frustration of the devil? The Lied has an impact, but the ambiguity of the intention supports what later commentators like Salmenhaara would identify as the contestability of Kilpinen's output (Salmenhaara 2001, 593).

\section{Der Tod und der einsame Trinker}

Eine Mitternachtszene

(Carietian Morgenutern)
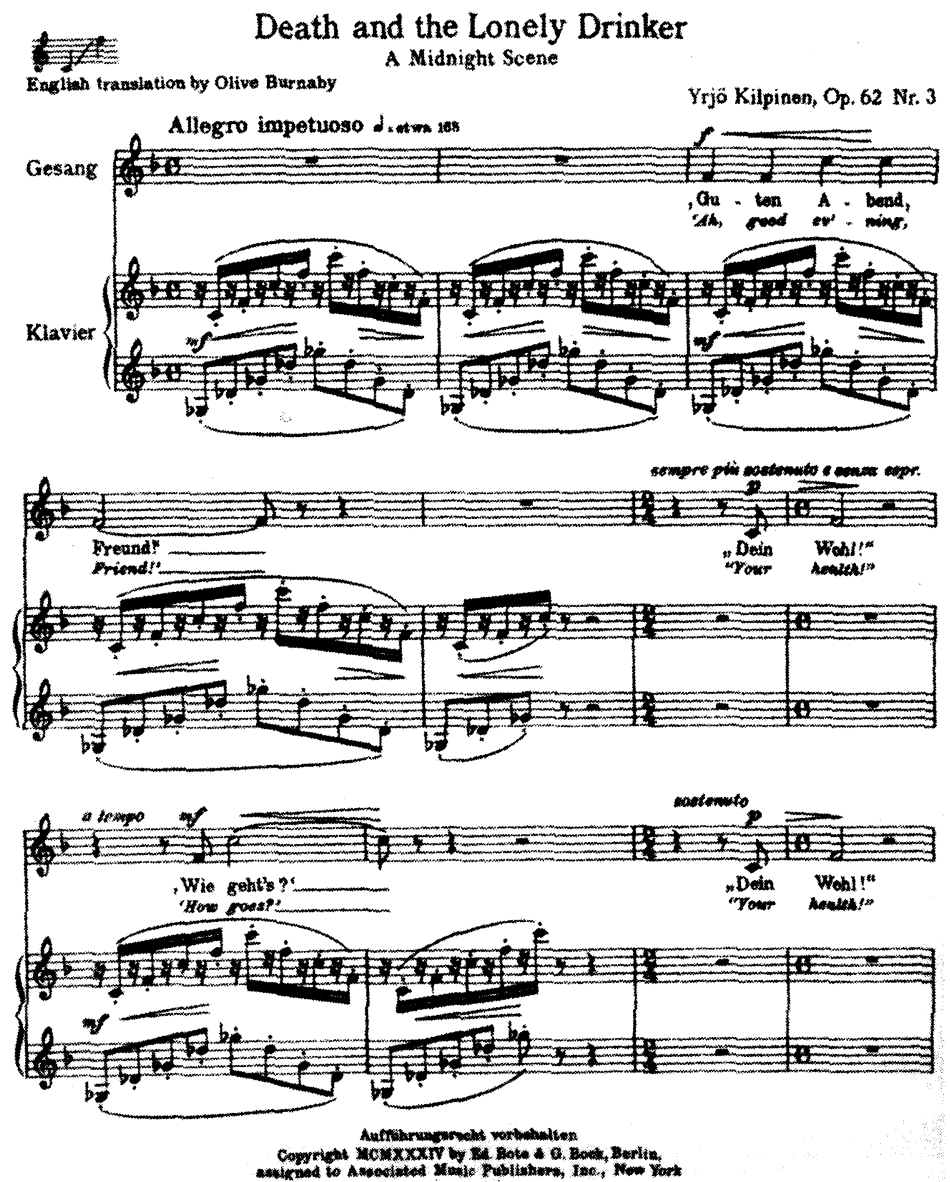

Example 3. Yrjö Kilpinen, /Lieder um den Tod/, Op. 62, No. 3: "Der Tod und der einsame Trinker." () Boosey \& Hawkes/Bote \& Bock, Berlin. Reprint with kind permission. 

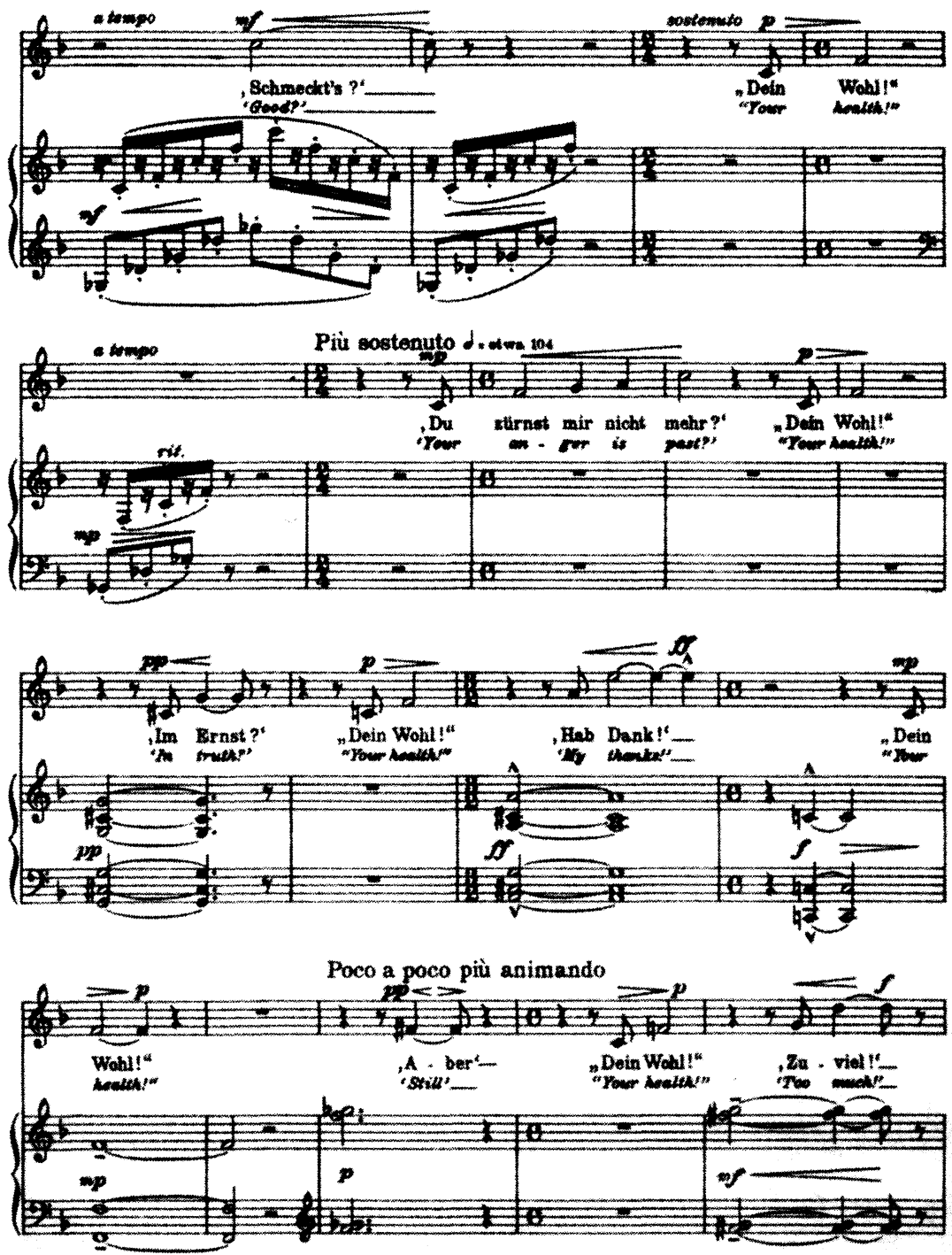

Example 3 (cont'd)

In general, the composer's economy of means calls to mind the miniatures of Robert Franz rather than the richly varied and complex songs of Schubert and Wolf, with notable exceptions, of course. In this regard, he also remained untouched by the influence of Sibelius's important song oeuvre. Kilpinen seems concerned with using one powerful and obvious musical gesture throughout a song, this use of ostinato having been drawn from the text. In some cases, like "Der Tod und der einsame Trinker," this involves obvious word painting, whereas in "Vöglein Schwermut," we find the composer 


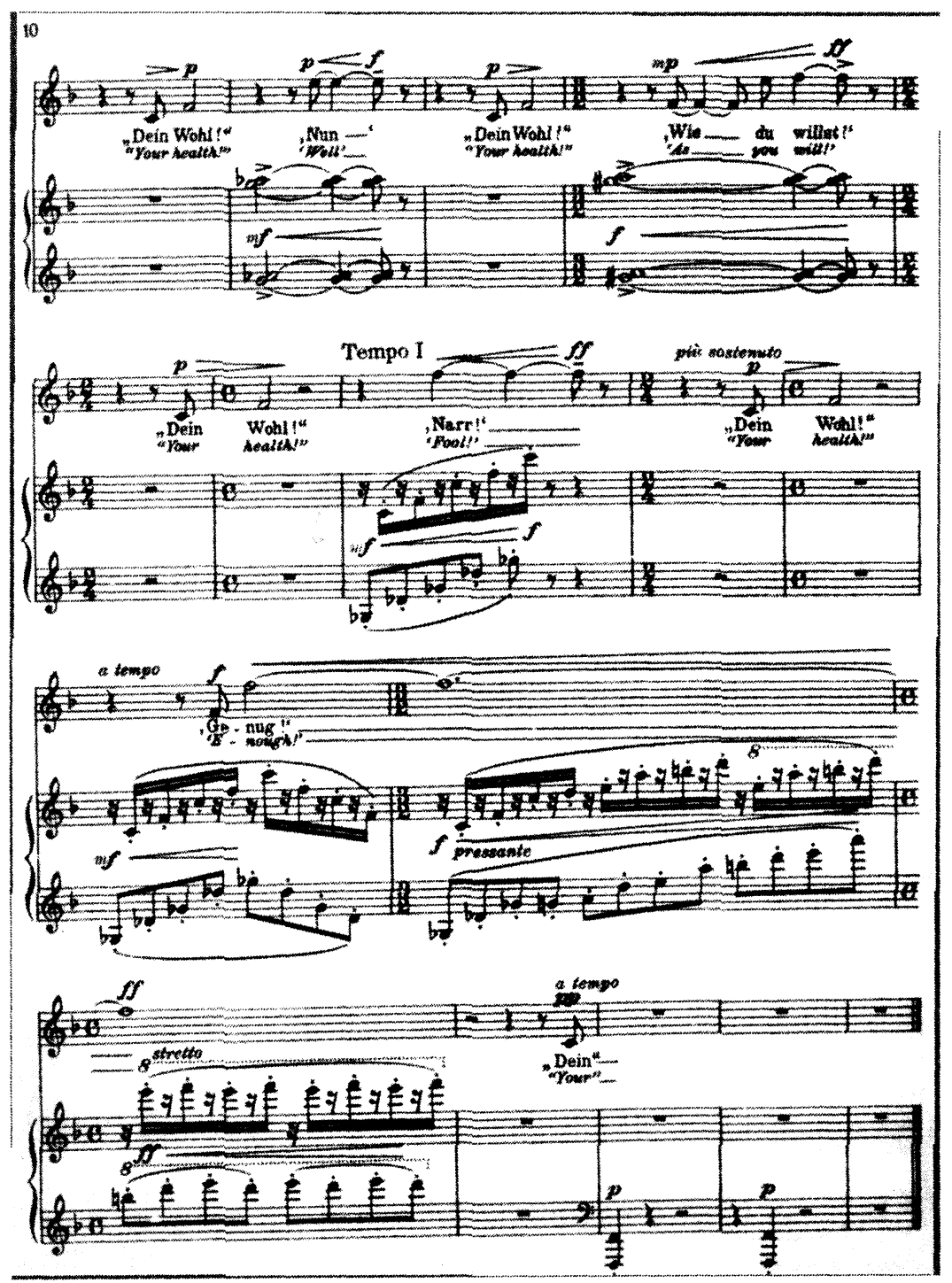

Example 3 (cont'd)

translating the general mood of the poem into music. In what pertains to the elemental effect of these songs, one is compelled to think of the Nazi aestheticians' emphasis on the Nordic musical invocation of the austere landscape.

\section{Concluding Remarks}

Kilpinen's apparent investment in the politics of National Socialism constituted a problem for Finnish music historians immediately after the war. They had difficulty enough convincing the world that Sibelius did not have per- 
sonal ties to the National Socialists in Germany. Kilpinen himself took steps to make it easier for his Finnish apologists in the post-war period: writing in 1996, Salmenhaara observed how Kilpinen composed a vocal cycle called Katri Vala-sarja in 1946 to the poems of a well-known Finnish leftist radical poet in order to polish his political reputation (Salmenhaara 1996, 500). Slightly later, Mäkelä phrases it this way: "in order to substantiate his efforts at an ideological re-orientation, Kilpinen set in 1946 Katri Vala's radically expressionistic texts and 64 Lieder from Lönnrot's Kanteletar" (Mäkelä 2003, 101). ${ }^{30}$ This rather sudden ideological about-face certainly strengthens the argument for Kilpinen's opportunism, although it does not in itself invalidate any possible national socialist aspirations on the composer's part.

Still, his past would pursue Kilpinen for the rest of his life and would make any assessment of his position in Finnish musical life problematic. Kilpinen has played such a minor role in post-war Finnish musical life and scholarship that one author of the 1990s wrote of "re-discovering" him (Borg 1992, 14). Certainly the contested quality of his music may have been one reason for the general silence, yet after the Kilpinen centenary in 1992, two noted Finnish scholars argued for a re-appraisal of the composer (Salmenhaara 1992, 1-2; Tarasti 1992, 48-54). Salmenhaara followed this call with his own contributions to the understanding of Kilpinen, ${ }^{31}$ though these assessments (like others to date) could not draw upon archival materials in the Finnish National Archive. In the absence of definitive proof of Kilpinen's personal involvement in National Socialism, Finnish commentators have had to walk a fine line. Korhonen merely observes "it was not altogether advantageous for his [Kilpinen's] later reputation that he was extremely popular in Nazi Germany ... We should note, though, that he was also highly regarded in Britain, where the Kilpinen Society was founded in 1935" (Korhonen 2003, 71). This reference to the British Kilpinen Society (founded in 1935 by Walter Legge) highlights an interesting aspect of Kilpinen reception: Legge himself exhibited Nazi sympathies. After all, he promoted Furtwängler in Britain and "discovered" Nazi party member Herbert von Karajan, and after the war married former party member Elisabeth Schwarzkopf. ${ }^{32}$ As a result, references to the British Kilpinen Society should also be suspect, at least as a means to deny possible associations with National Socialism on the composer's part (Mäkelä $2003,100) .{ }^{33}$ The Yrjö Kilpinen Society of North America, Ltd. (a populist

30 "Um sein Bemühen um weltanschauliche Umorientierung zu belegen, vertonte er 1946 Katri Valas radikal expressionistische Texte und 64 Lieder zu Lönnrots Kanteletar."

31 For example, the aforementioned article in The New Grove Dictionary of Music and Musicians and extended discussion in Uuden musiikin kynnyksellä.

32 Despite his significance for the history of recording, Legge has not yet served as the subject for a scholarly monograph. Schwatzkopf has published a memoir of him (1982) and Alan Sanders has edited his letters and writings (1988), neither of which provide significant insights into his personal associations with the Nazis.

33 Like Korhonen, Mäkelä refers to the founding of the British Kilpinen Society in 1935 as a counter-balance to his popularity in Nazi Germany. Salmenhaara $(1996,499-500)$ recounts the 
society founded in 1999 "to honour and cherish the artistic memory of the great Finnish composer") does not have the same political background, yet it also fails to recognise any politically problematic aspects of his past, suggesting that he was merely a typical composer who kept aloof from politics (Yrjö Kilpinen Society 2005).

Much work remains to be undertaken on Kilpinen and his music. Of course, definitive conclusions about the interaction of his biography, aesthetics and politics will have to await the release of his letters, yet that is no reason for us not to engage with his music and its meanings. As is evident from this investigation, political allegiances can lead to unexpected aesthetic results, to the extent that the Finn Kilpinen was accepted in National Socialist Germany as a master of the Lied. The revelation and explanation of this irony may represent a small step towards the understanding of composer and context, yet it also moves us ahead in the needed discussion of how we can speak about music in a way that engages sounds and politics, text and context, in a fruitful dialogue.

\section{Reference List}

Altmann, Wilhelm. 1942. "Statistischer Überblick über die im Winter 1941/42 stattfindenden Reihenkonzerten." Zeitschrift für Musik 109, no. 2 (February): 54-61, no. 3 (March): 102-10.

Blinkhorn, Martin. 2000. Fascism and the Right in Europe, 1919-1945. Harlow: Pearson Education.

Borg, Kim. 1992. "Yrjö Kilpinen: A Song Writer (Re)discovered." Nordic Sounds, no. 1: 14-16.

Buckbee, G.L. 1988. "Yrjö Kilpinen The Morgenstern Period." Finnish Musical Quarterly 3: 26.

Bücken, Ernst. 1939. Das deutsche Lied: Probleme und Gestaltern. Hamburg: Hanseatische Verlagsanstalt.

Evans, Joan. 2003. "International with National Emphasis": The Internationales Zeitgenössisches Musikfest in Baden-Baden, 1936-39. In Musik and Nazism: Art under Tyranny, 1933-1945, ed. Michael H. Kater and Albrecht Riethmüller, 102-13. Laaber: Laaber-Verlag.

. 2003. "Stravinsky's Music in Hitler's Germany." Journal of the American Musicological Society 56, no. 3 (Fall): 525-94.

Gerigk, Herbert. 1942. "Kilpinen 50 Jahre alt." Die Musik34, no. 5 (February): 182.

Gleißner, Ruth-Maria. 2002. "Der unpolitische Komponist als Politikum: Die Rezeption von Jean Sibelius im NS-Staat," in: Europäische Hochschul-

founding of this society, too, albeit not as a counter-balance. He mentions Kilpinen's promoters in England as Legge and the singers Gerhard Hüsch and Astra Desmond. In the same context Salmenhaara also recounts how Kilpinen and Hüsch went on touring together in Germany during the war 1942-43. 
schriften, Series 16: Musikwissenschaft, Vol. 218. Frankfurt a.M.: Peter Lang.

Graener, Paul. 1937. "Zeitschriften-Schau: Begegnung mit Kilpinen." Zeitschrift für Musik 104, no. 1 (January): 5-6.

Hapke, Walter. 1936. "Musik im Rundfunk. Reichssender Hamburg." Zeitschrift für Musik 103, no. 1 (September): 1152.

Helasvuo, Veikko. 1952. Sibelius and the Music of Finland. Helsinki: Otava.

Ingman, Lauri. 1930. Die Lapua-Bewegung in Finnland. Helsinki: Staatsdrückerei.

Karila, Tauno. 1964. Yrjö Kilpinen: säveltäjäkuvan ääriviivoja. Porvoo: W. Söderström.

Korhonen, Kimmo. 2003. Inventing Finnish Music-Contemporary Composers from Medieval to Modern. Helsinki: Finnish Music Information Centre.

Larsen, Stein U. 1990. "Conservatives and fascists in the Nordic countries: Norway, Sweden, Denmark and Finland, 1918-45." In Fascists and conservatives: the radical right and the establishment in twentieth-century Europe, ed. Martin Blinkhorn, 240-63. London: Unwin Hyman.

Mäkelä, Tomi. 2003. "Kilpinen, Yrjö (Henrik)." In Die Musik in Geschichte und Gegenwart, $2^{\text {nd }}$ ed. 100-1. Kassel: Bärenreiter.

Pfohl, Ferdinand. 1935. "Das Tonkünstlerfest in Hamburg." Zeitschrift für Musik 102, no. 7 (July): 751-56.

Prieberg, Fred K. 1982. Musik im NS-Staat. Frankfurt a.M.: Fischer.

Rudolf, Herbert. 1938. 'Sieg der Ehre und der Wahrheit. 'VB.'-Gespräch mit Yrjö Kilpinen, dem bekannten finnischen Komponisten." Völkischer Beobachter, North German edition, no. 275 (October 2): 7.

Salmenhaara, Erkki. 1992. "Yrjö Kilpinen." In Komponisten der Gegenwart: Loseblatt-Lexikon. 1-2. Munich: text + kritik.

. 1996. Uuden musiikin kynnyksellä. Suomen musiikin historia, 3. Porvoo: WSOY.

. 2001. Kilpinen, Yrjö (Henrik). In New Grove Dictionary of Music and Musicians, $2^{\text {nd }}$ ed. Vol. 13, 593-94. London: Macmillan.

Sanders, Alan. 1988. Walter Legge: Words and Music. London: Duckworth.

Schwatzkopf, Elisabeth. 1982. On and Off the Record: A Memoir of Walter Legge. Boston: Northeastern University Press.

Stege, Fritz. 1936. "Sibelius und die nordische Tonwelt. Zum 70. Geburtstag des finnischen Meisters." Hochschule und Ausland 14, 44-50.

. 1939. "Yrjö Kilpinen." Zeitschrift für Musik 106, no. 9 (September): 921-30.

Tarasti, Eero. 1992. "Yrjö Kilpinen: Suomalaisen liedin mestari." Synteesi 11, no. 4: 48-54.

Taurula, Tarja. 1998. Yrjö Kilpinen: Sävellykset. Helsinki: Finnish Music Information Centre.

Yrjö Kilpinen Society of North America, Ltd. 2005. http://www.kilpinen.org (accessed 6 May 2005). 


\begin{abstract}
The Lieder of Finnish composer Yrjö Kilpinen (1892-1959) provide an interesting opportunity to study the interaction of national identity and musical aesthetics in National Socialist Germany. His German-language songs, above all to texts by Christian Morgenstern, enjoyed considerable success in Germany of the 1930s. Kilpinen's own political sympathies made him a model for Nazi ideologists, even as a non-German composing in the quintessentially German musical genre of the Lied. Reviews of his Lieder in the German-language press expound on the "Nordic" qualities of the work of this "Aryan" composer. Closer examination of the Lieder um den Tod reveals a stark, at times heavy-handed compositional technique, which well suited the political ideology of the Third Reich.
\end{abstract}

\title{
RÉSUME
}

Les lieder du compositeur finnois Yrjö Kilpinen (1892-1959) offrent une intéressante occasion d'étudier l'interaction entre l'identité nationale et les esthétiques musicales présentes dans l'Allemagne nationale-socialiste. Ses chants en allemand, surtout ceux composés sur les textes de Christian Morgenstern, ont connu une grande popularité dans l'Allemagne des années 1930. Ses affinités politiques ont transformé Kilpinen en modèle des idéologues nazis, ce malgré le fait qu'il n'était pas Allemand et composait dans le genre allemand par quintessence qu'est le lied. Les critiques de ses lieder parues dans la presse allemande expliquaient dans le détail les qualités " nordiques " de l'œuvre de ce compositeur " aryen ". Une étude plus approfondie des Lieder um den Tod révèle une technique compositionnelle rigide, parfois même maladroite, qui s'adaptait bien à l'idéologie politique du Troisième Reich. 